\title{
AsthMA CONTROL LIMITATIONS IN SELECTED PRIMARY HEALTH CARE CLINICS
}

\author{
Authors: \\ Jesslee M. du Plessis ${ }^{1}$ \\ Jan J. Gerber ${ }^{1}$ \\ Affiliations: \\ ${ }^{1}$ Department of Clinical \\ Pharmacy, North-West \\ University, South Africa
}

\section{Correspondence to:}

Jesslee Melinda du Plessis

\section{e-mail:}

jesslee.duplessis@nwu. ac.za

\section{Postal address:}

North West University

(Potchefstroom Campus),

Private Bag X6001,

Potchefstroom, 2520,

South Africa

\section{Keywords:}

health care; record

keeping; asthma control;

documentation; quality

\section{Dates:}

Received: 05 Feb. 2009

Accepted: 29 July 2009

Published: 19 Oct. 2009

How to cite this article: Du Plessis, J.M. \&

Gerber, J.J. 2009, 'Asthma control limitations in selected primary health care clinics', Health $S A$ Gesongheid 14(1), Art. \#421, 3 pages. DOI: $10.4102 /$ hsag.v14i1.421

\section{This article is available} at: http://www.hsag.co.za
(C) 2009. The Authors. Licensee: OpenJournals Publishing. This work is licensed under the Creative Commons Attribution License.

\begin{abstract}
Primary health care services worldwide are currently experiencing many quality-related problems. Efforts to improve these services appear to be sporadic and unsatisfactory. Investigations have revealed (Sharma \& Sharma 2007) that one of the main causes for this state of affairs can be identified as neglected or inadequate documentation of patient/case history. The health care provider (HCP) should be equipped to improve the quality of health care and to take the lead in assuaging the predicament.
\end{abstract}

The present study was undertaken to assess the correlation between asthma control and patientrelated case history notes as recorded via the HCP. The data were obtained retrospectively from the patient notes of all asthmatic patients (including children and pregnant women) who attended six selected clinics in the North West Province of South Africa (Dr Kenneth Kaunda Municipal District).

The analysis of the data collected from the patient clinic books confirmed the suspicion of poor quality of documentation, although the documentation in certain categories rendered some positive results. When compared to the GINA® guidelines, none of the patients had been controlled properly and only a small number (18.4\%) had been controlled partly (GINA 2008). Asthma control may be enhanced when a standard template is developed for completion by the HCP. It is envisaged that this will ensure that vital information regarding asthma control is documented in order to contribute to satisfactory chronic disease control.

\section{OPSOMMING}

Primêre gesondheidsorgdienste wêreldwyd ondervind tans menige gehaltediens-verwante probleme, terwyl pogings om dit te verbeter sporadies en onbevredigend voorkom. Navorsing toon (Sharma \& Sharma, 2007) dat een van die hoofoorsake hiervan die onvoldoende dokumentasie van die pasiënt of die geval se geskiedenis of nalating om te dokumenteer, is. Die gesondheidsorgverskaffer (GSV) moet toegerus word om die gehalte van gesondheidsorg te verbeter en leiding te neem om die verknorsing te hanteer.

Hierdie studie het die korrelasie tussen asmabeheer en pasiëntgeskiedenis, soos genoteer deur 'n GSV, ondersoek. Dié data is retrospektief van die klinieknotas van alle asmapasiënte (kinders en swanger vroue ingesluit) verkry wat die ses klinieke in Noordwes Provinsie, Suid-Afrika (Dr. Kenneth Kaunda Munisipale Distrik), besoek het.

Die analise van die data wat uit pasiënte se kliniekboekies versamel is, het die vermoede oor die swak gehalte van dokumentasie bevestig, alhoewel daar positiewe uitkomste was in sekere kategorieë se dokumentasie. Wanneer die dokumentasie met die GINA®-riglyne vergelyk word, is dit duidelik dat geen van die pasiënte optimaal bestuur is nie en slegs ' $n$ klein groepie (18.4\%) gedeeltelik bestuur is (GINA 2008). Asmabeheer sou kon verbeter deur 'n standaard templaat te ontwikkel wat die GSV kan voltooi. Daar word voorsien dat dit die dokumentering van die nodige inligting oor asmabeheer sal verseker en sodoende kan bydra tot die bevredigende bestuur van kroniese siektes.

\section{INTRODUCTION}

Asthma is a chronic disease of the body's bronchial (airway) tissues. This inflammatory condition afflicts millions of people worldwide (Dimond 2005:460). Despite national and international guidelines for the diagnosis and management of asthma, asthma morbidity remains a significant health problem (Stanbrook \& Kaplan 2008:1099). Enhancing the quality of health care (Laurant et al. 2005:CD001271) can improve asthma control but, in most systems, poorly controlled asthma still imposes a considerable burden. These issues are particularly important and relevant in primary care, where most asthma cases are managed.

Several factors influence the true prevalence of asthma, namely misdiagnosis (Miedinger et al. 2007:1760; Nepal \& Bhattarai 2008:1; Stanbrook \& Kaplan 2008:1099; Tinkelman et al. 2006:75), poor documentation of history taking and clinical examination (Owen 2005:48), and the shortfall of a single objective diagnostic test (GINA® 2008; MayoClinic.com n.d.; Oppenheimer \& Li 2006:119). A lack of awareness of achievable control and the underestimation of the significance of symptoms handicap the aim of asthma management, which is to achieve and maintain asthma control (Oppenheimer \& Li 2006:119). This study was undertaken to establish the limitations in documentation (notes documented by HCP in clinics) (Liyanage et al. 2006:187) and the impact thereof on asthma control (Oppenheimer \& Li 2006:119).

\section{RESEARCH METHOD}

A retrospective review was conducted on the clinical notes of all patients who had received treatment for chronic asthma (children and pregnant women included). The patients were those who attended six primary health care clinics in the Dr Kenneth Kaunda District of South Africa (Potchefstroom). The documentation (WHO 2007) was evaluated in order to determine the impact that proper or inadequate notes might have had on the quality and outcomes of relevant health care (Feld 2007). All the asthmatic patients who attended the above-mentioned clinics were recruited as participants, provided that they 
had signed an informed consent form. The HCP managing the patient informed them about the project and the possibility of being part of it, after which the consent form was signed. Patient information remained anonymous. The Ethics Committee of the North-West University granted approval for the research to be carried out. An eight-point scale developed by the investigator was used as the method for evaluating the data. This scale looked at the physical recordings by the HCP of eight different recordable variables, i.e. variables defined as symptoms (tight chest or chest pains, shortness of breath, cough and wheezing), peak flow readings, diagnosis, smoking habits and a 'to come back' date. All variables were taken into account if documented, irrespective of accuracy.

\section{Validity and reliability}

No measuring instrument was used in this study. Data was gathered simply by collecting documented information from patient records as set out by the eight-point scale. The focus was explicitly on shortcomings regarding documentation comprehensiveness and the effect thereof on asthma control.

\section{RESULTS}

It was found from analysing the patients' medical records that an alarming $96 \%$ of the documentation was inadequate or lacking in the area of night symptoms. Only five of the patients had data recorded under 'night symptoms', and three of the five were documented as having no symptoms in this area. During the planning of the study, 'night symptoms' were deemed to be part of a nine-point measuring tool for the control of asthma. However, due to the lack of data, 'night symptoms' was not utilised as part of the measuring tool, and analyses were done on the remaining eight variables.

Of the 125 investigated patients, $80(64.0 \%)$ were uncontrolled if a peak flow percentage of 60 was taken as a cut-off margin. The mean peak flow percentage for the patients was $46.0 \%$ (range: 17.0 to $78.0 \%$ ). From these results it is also clear that none of the patients reached a well-controlled margin of $80 \%$. For this reason the controlled versus uncontrolled benchmark was set at $60 \%$ (GINA 2008) Thorsteinsdottir et al. 2008:814).

Table 1 shows the percentage of documented clinical notes in each of the different categories. From this it is clear that some areas (peak flow reading, 'to come back' dates, diagnosis and smoking habits) received more attention than others. When this was investigated further it seemed that these salient areas already had a specific form for documentation purposes in the clinics. The documentation of the four symptom variables showed a particularly low figure. In fact, if the four symptoms were to be bundled together in an 'all-or-none' manner (Kelly 2007:1), data for only four patients $(3.2 \%)$ could be considered fully documented.

Table 2 shows a meaningful and statistically significant improvement $(p=0.01)$ in the control of asthma (measured by means of peak flow) when the documentation of the data variables has been improved, despite the fact that four of the variables already improved due to a basic tick-box on a clinic visit form.

TABLE 1

Documented clinical notes

\begin{tabular}{ll}
\hline & $\%$ \\
\hline Peak flow reading & 82.4 \\
To come back & 80.0 \\
Diagnosis & 73.6 \\
Smoking habits & 49.6 \\
Wheeze & 18.4 \\
Shortness of breath & 12.8 \\
Cough & 12.8 \\
Tight chest/Chest pain & 12.0 \\
\hline
\end{tabular}

TABLE 2

Documentation and asthma control

\begin{tabular}{lll}
\hline & $\begin{array}{l}\text { UNCONTROLLED } \\
\text { ASTHMA }\end{array}$ & $\begin{array}{l}\text { CONTROLLED } \\
\text { ASTHMA }\end{array}$ \\
\hline Up to two variables documented & $95.45 \%$ & $4.55 \%$ \\
Three or more variables documented & $72.84 \%$ & $27.16 \%$ \\
\hline
\end{tabular}

\section{DISCUSSION}

Health care providers need to take appropriate action if asthma control is found to be poor (Expert Panel Report 3 2007:S94; Van Weel et al. 2008:997), but the results show that the opposite is happening. Sixty-four percent of the patients were uncontrolled and yet no therapy adjustments were visible. HCPs often seem to consider asthma to be controlled, even when, according to current guidelines, it is not. The level of asthma control is completely overestimated. The question is: 'Is the level of achieved asthma control a direct reflection on HCP behaviour, or merely on the misconception of asthma as an untreatable disease?' (Stanbrook \& Kaplan 2008:1099).

Asthma is a chronic but treatable condition. It cannot be cured but careful management can help avoid recurrent attacks and thereby help with control (GINA 2008). The current focus has shifted from managing severity symptoms to rather using asthma control as an outcome measure (Oppenheimer \& Li 2006:119).

The use of patient records for achieving alignment with HCPs to improve patient care and ensure quality ratings tends to be a very helpful tool (Owen 2005:48; Pullen \& Loudon 2006:280; Van Weel et al. 2008:997). If the keeping of records is not in place or done accurately, many important aspects are not mentioned and cannot be taken into consideration for future planning for management. The content of the documented notes on each HCP-patient contact was investigated. It was of inferior quality, especially in certain areas such as symptoms, and almost all of the patients were in an uncontrolled state, with minimal to no action taken to improve the situation.

Primary health care clinics suffer certain limitations, e.g. understaffing, lack of time for educational programmes, limited time per patient and other difficulties (Primary Health Care 2007). An understanding of these circumstances results in a search for alternative options by means of which to improve the $\mathrm{HCP}^{\prime}$ 's clinical documentation methods.

\section{CONCLUSION}

Poor clinical patient notes (two or fewer variables documented) have been linked to both poor quality of care and uncontrolled asthmatics. The converse has also proven to be true. Good practices in clinical documentation, with more efficient and higher quality documentation, will lead to improved HCP and patient satisfaction. While we may not have the ability to affect the way HCPs practice medicine, we have the ability, and an obligation, to shape the way they document patients information. The importance of this is that the focus should not only be on the problem identified, but should also include suggestions for improvement.

\section{RECOMMENDATIONS}

The next step would be to start working on a pre-selected, functionally designed data recording form that is specifically and carefully designed according to asthma guidelines and that will be effective in primary care clinics for quick but complete and easy notation.

\section{ACKNOWLEDGEMENTS}

The authors gratefully acknowledge the support of Dr Claire van Deventer; the clinic staff and all team members involved at the primary health care level. We also thank the Department of 
Health, Dr Kenneth Kaunda District Municipality, Dr Suria Ellis from the Department of Statistics, North-West University, for her support on the statistical level, and finally, we would like to thank the personnel at the North-West University, School of Pharmacy, who helped in any way, even if it was purely to provide moral support to the authors.

\section{REFERENCES}

Dimond, B., 2005, 'Exploring the principles of good record keeping in nursing', British Journal of Nursing 14(8), 460-462.

Disease Control Priorities Project, 2002, Primary health care: Key to delivering cost-effective interventions, viewed 10 November 2008, from http://www.dcp2.org/file/77/DCPP PrimaryHealthCare.pdf.

Expert panel report 3 (EPR-3), 2007, 'Guidelines for the diagnosis and management of asthma - summary report 2007', Journal of Allergy and Clinical Immunology 120(5), S94-S138.

Feld, S., 2007, Repairing the healthcare system: What is the definition of quality medical care?, viewed 10 November 2008, from http://stanleyfeldmdmace.typepad.com/repairing_the_ healthcare_/2007/03/what_is_the_-def.html.

(GINA 2008), Global strategy for asthma management and prevention, viewed 10 November 2008, from http://www.ginasthma. org/download.asp?intId=345.

Kelly, E., 2007, 'All or none measurement: Why we know so little about the comprehensiveness of care', International Journal for Quality in Health Care 19(1), 1-3.

Laurant, M., Reeves, D., Hermens, R., Braspenning, J., Grol, R. \& Sibbald, B., 2005, 'Substitution of doctors by nurses in primary care', Cochrane Database System Review 18(2), CD001271.

Liyanage, S.E., Thyagarajan, S., Khemka, S., Blades, M. \& De Alwis, D.V., 2006, 'Audit of the quality of documentation in an eye casualty department', Clinical Governance: An International Journal 11(3), 187-192.
MayoClinic.com, n.d., Asthma, viewed 10 November 2008, from: http://www.mayoclinic.com/health/asthma/DS00021.

Miedinger, D., Chhajed, P.N., Tamm, M., Stolz, D., Surber, C. \& Leuppi, J.D., 2007, 'Diagnostic tests for asthma in firefighters', Chest 131(6), 1760-1767.

Nepal, M. \& Bhattarai, M.D., 2008, 'Misdiagnosis of COPD in middle-aged asthmatics in Nepal', The Internet Journal of Pulmonary Medicine 10(1).

Oppenheimer, J.J. \& Li, J., 2006, 'Attaining asthma control', Current Opinion in Allergy and Clinical Immunology 6(2), 119123.

Owen, K., 2005, 'Documentation in nursing practice', Nursing Standard 19(32), 48-49.

Pullen, I. \& Loudon, J., 2006, 'Improving standards in clinical record-keeping', Advances in Psychiatric Treatment 12, 280286.

Sharma, P. \& Sharma, R., 2007, 'Medical case note-keeping \& documentation practices', The Internet Journal of Healthcare Administration 5(1).

Stanbrook, M.B. \& Kaplan, A., 2008, 'The error of not measuring asthma', CMAJ 179(11), 1099-1100.

Thorsteinsdottir, B., Volcheck, G.W., Madsen, B.E., Patel, A.M., Li, J.T.C. \& Lim, K.G., 2008, 'The ABCs of asthma control', Mayo Clinic Proceedings 83(7), 814-820.

Tinkelman, D.G., Price, D.B., Nordyke, R.J. \& Halbert, R.J., 2006, 'Misdiagnosis of COPD and asthma in primary care patients 40 years of age and over', Journal of Asthma 43(1), 75-80.

Van Weel, C., Bateman, E.D., Bousquet, J., Reid, J., Grouse, L., Schermer, T., Valovirta, E. \& Zhong, N., 2008, 'Asthma management pocket reference 2008', Allergy 63(8), 997-1004.

World Health Organization, Guidelines for medical record and clinical documentation, viewed 10 November 2008, from www.searo.who.int/LinkFiles/2007_Guidelines_for_ Clinical_Doc.pdf. 